modern idea of autonomy as self-determination). Both authors appear to assume that Nietzsche has one ideal type under which all his descriptions of what is übermenschlich has to fit. But it is not clear that this is true.

27. Cicero On Duties, ed. M.T. Griffin and E.M. Atkins (Cambridge: Cambridge University Press, 2004), p. 139.

28. F. Nietzsche Twilight of the Idols/The Anti-Christ (hereafter cited as TI) trans. R.J. Hollingdale (London: Penguin Books, 1990), p. 96, 104.

29. Nietzsche provides further examples in Twilight of the Idols of what this training and exercise of the will involves. In order to see well, for instance, we must learn to defer judgment: "not to react immediately to a stimulus, but to have the restraining, stock-tacking instincts in one's control." The incapacity to resist a stimulus, the need to react and obey every impulse, is a sign of "decline" and "symptom of exhaustion." (TI 76) We must submit to these kinds of exercises to have our volitional and cognitive resources in our control. 


\section{TOWARDS THE REHABILITATION OF THE WILL IN CONTEMPORARY PHILOSOPHY VINCENT BLOK}

\section{Introduction}

In the twentieth century, the concept of the will acquired a bad reputation. Already Nietzsche speaks negatively about a will to truth:

"Will to truth", you who are wisest call that which impels you and fills you with lust? A will to the thinkability of all beings: this I call your will. You want to make all being thinkable, for you doubt with well-founded suspicion that it is already thinkable. ${ }^{1}$

According to Nietzsche, the will to truth is the distortion of plurality into the same and the similar:

Thinking is a distorting transformation, feeling is a distorting transformation, willing is a distorting transformation -: all possess the ability to assimilate: it preconceives a will, something to make things equal to us (etwas uns gleich zu machen) (KSA 11: 506).

Yet Nietzsche eventually remains rather positive about the will. The will to truth is a necessary though insufficient condition for the preservation of life, which would otherwise evaporate in the face of relentless variability (the world of becoming). Together with the will to truth, he introduces the will to power as art. Art is the essence of willing, creating new perspectives and possibilities for the will. So for Nietzsche the concept of the will operates as a problem - the distortion of plurality that makes it look like a general concept (will to truth) and as its solution: the creation of new perspectives and possibilities for the will.

In the twentieth century the concept of the will was criticized in a more rigorous way. Emmanuel Levinas, for instance, criticizes the will as a movement of reducing otherness to sameness, difference to identity. ${ }^{2}$ In his diagnosis of the will he follows Martin Heidegger, one of the prominent critics of the will in the twentieth century. Since the latter's diagnosis of the will, the releasement from a wilful manner of thinking and the exploration of the possibility of non-willing has become a prevalent issue in contemporary philosophy. In the case of Heidegger, the main question is how to think a mode of 'thinking [which] would be something other than willing', a gelassen or nonwilling mode of philosophical thinking. ${ }^{3}$

According to several prominent philosophers, Heidegger's releasement of the will results in quietism, resignation or even fatalism. One of his students, Karl Löwith, already charged him with the mere reversion 'between wilfulness and sacrificing one's will'. While in Being and Time human existence (Dasein) is seen as active and resolute, in Heidegger's later work, Dasein is rather seen as 'opening-oneself-up-to the open, the unconcealed, that which is true in Being'. ${ }^{4}$ The same kind of criticism can be found in the work of Jürgen 
Habermas: 'The language of Being and Time had suggested the decisionism of empty resoluteness; the later philosophy suggests the submissiveness of an equally empty readiness for subjugation'. 5

This criticism is striking, because Heidegger, from the onset of his career, criticized the applicability of categories like activity and passivity to his concept of human existence in general and his concept of resoluteness (Entschlossenheit) in particular. ${ }^{6}$ With regard to his exploration of a gelassen or non-willing method of philosophical thinking, he makes quite clear that concepts like activity and passivity are inapplicable. ${ }^{7}$ Nevertheless, from Heidegger's 'reversion' of an active into a passive role of human existence with regard to Being, Herman Philipse concludes that Heidegger's seemingly "deep" critique of technology is nothing but pseudo-religious quietism disguised as a radical critique. The morally undesirable effect of this critique is that it condemns all real and fruitful criticism of technology as superficial, naïve, and insufficiently radical' ${ }^{8}$ In general, Heidegger's concept of Gelassenheit is interpreted as 'indifference' to ethical duties, as a quietism that withdraws from the world. ${ }^{9}$ What these authors fail to see, is that Heidegger does not embrace quietism, but puts into question this whole distinction between active and passive. Or as Bret Davis has pointed out convincingly in his monumental study of Heidegger and the will, his thought of "a human "cor-respondence" to the "needful-usage" of Being resists the criticism that man is reduced to "impotence" and being elevated to "omnipotence". ${ }^{10}$

Nevertheless, Heidegger's critics pose the legitimate question whether we have to reject the will in such a radical way. ${ }^{11}$ Does a fruitful criticism of the will not already involve a certain form of striving, of willing? We could even ask whether a phenomenology of willing is ever thinkable without a moment of willing, without deliberately intending something (orexis). Is there, in other words, not a third position possible beyond willing and non-willing, a concept of willing which transcends the reduction of otherness to sameness, difference to identity. This safe course between Scylla - the reductive will - and Charybdis - the releasement of willing - cannot be found in an uncritical embrace of the will nor in its blunt rejection. As we know, Scylla lies perilously close to Charybdis. How shall we navigate? What ensures a safe passage between them, if not the concept of the will itself?

Less known is that Heidegger himself also attempted to develop a proper concept of the will, to characterize his philosophical method in the early thirties. In the opening paragraph of his Rectoral Address of 1933 for instance, he starts with the 'spiritual mission' of the university that must be willed and he ends this lecture with the remark that 'it is our will that our people (Volk) fulfil its historical mission. We will ourselves'. ${ }^{12}$

As I argued elsewhere, Heidegger's embrace of the will in the early thirties does not testify to a 'massive voluntarism' or 'existential voluntarism' in his 
thought, as Jacques Derrida and Brett Davis have suggested..$^{13}$ On the contrary, it will become clear that Heidegger's embrace of the will is due to his phenomenology of the concept of the will and that he only used the concept of the will in this way in the onset of the thirties (cf. §1). Could Heidegger's concept of the will help us to find a compass-point that lies between Scylla and Charybdis, and ultimately, help us to develop a proper concept of willing? In this article we shall critically discuss and continue Heidegger's phenomenology of the will in order to develop such a proper concept of willing.

In section 1 we summarize Heidegger's phenomenology of the will as expounded in his lecture course of 1930, in which he discusses the 'pure will' of Kant's practical philosophy. We will distinguish three main characteristics of Heidegger's concept of the will. These three characteristics will subsequently be traced in his phenomenology of willing of the mid-thirties (1936/37), in which he discusses Nietzsche's will to power as art. In section two, the question will be answered whether Heidegger's concept of the will can help us to find a path between Scylla and Charybdis. By following the intimations of Heidegger's phenomenology of willing, we are able to identify some limitations of Heidegger's later rejection of the will and offer our own thoughts on how to build on Heidegger's phenomenology of willing. With this, we rehabilitate a proper concept of willing.

\section{Heidegger's Phenomenology of the Will ${ }^{14}$}

i. Heidegger's Phenomenology of the Will in his Confrontation with Kant (1930)

In 1930 Heidegger gave a lecture course on the essence of human freedom. In the final part of this course, Heidegger appropriates the 'pure will' of Kant's practical philosophy. In the Critique of Practical Reason of 1788, Kant showed that the pure will provides the basis for practical freedom by revealing universal laws (the categorical imperative).

According to Kant, the will is 'a faculty [...], either of bringing forth objects corresponding to representations, or of determining itself, i.e. its causality to effect such objects'. ${ }^{15}$ In accordance with the philosophical tradition, Kant distinguishes between two capacities of the will. The will can be conceived as the capacity to determine one's causality; it is the capacity to bring forth objects that correspond to (rational) representations. This determining ground for the will can be found in the ((rational) representation of the) object which have to be effected, or in the capacity to determine oneself in one's causation, i.e. the freedom to cause such striving to bring forth these objects. Only in the second case is the will not determined by an external cause. Heidegger interprets this in the following way: "Now if will can determine its own causation, it has the possibility of determining itself in its causation through itself. [...] In this case willing takes its determining ground not from somewhere else but from itself. And what does willing take from itself? It takes 
itself, in its essence' ${ }^{16}$ Heidegger is primarily interested in this second sense of willing in his lecture course from 1930. There is no external cause of this capacity of willing, which means that the cause of willing is actual willing itself: 'Pure willing is the willing of one's own essence as will' (GA 31:278). This willing is called pure, because only this type of willing is purely determined through itself.

Although it is not directly clear why pure willing is the point of departure for Heidegger's conception of the will - and not, for instance, the will as it is determined by the world as that which is willed (we will come back on this point in section two) - we will now closely follow Heidegger's reasoning in his phenomenology of the will in his 1930 lecture course.

Following Kant in his Critique of Practical Reason, Heidegger argues that the causality of something has to be understood as the law of the existence of something; it is the law according to which something comes into existence. If pure will is understood as self-causation, therefore, it has to be conceived as the law for the existence of the will: 'When this [pure will] alone is determining, then the law of pure will is nothing else than the form of law-giving for a pure will' (GA 31: 278-279). What is law-giving for willing is therefore actual pure willing itself.

The question arises, however, what kind of will it is which purely wills itself. Following Kant, Heidegger argues that such a will unconditionally determines its own willing. 'It cannot help but be in harmony with itself, its pure essence, i.e. it cannot but be good. And a will that cannot but be good is a perfectly good will, or as Kant says, a holy, divine will' (GA 31: 280). But in case of finite beings like humans, the will is not in harmony with itself because it is determined by other motives too, and by its sensibility. How do we have to conceive actual willing in the case of finite pure willing? Whereas in 'divine willing' the law of willing is found in the pure willing of the will, in the case of finite pure willing it is found in 'the ought of pure willing' (GA 31:280); the law-giving of finite pure willing has the character of an imperative, i.e. of a 'you ought'.

And here we reach the point where Heidegger's confrontation with Kant's concept of the will commences. According to Heidegger, the problem resides in the question of the actuality of this law of finite pure willing. Kant did not ask this question:

However, Kant remains a long way from explicitly making this factuality as such into a central metaphysical problem, i.e. from bringing its conceptual articulation over into the essence of man and thus arriving at the threshold of a fundamentally different problematic (GA 31:294).

According to Kant we become conscious of the categorial imperative 'as soon as we construct maxims for the will' (CPR: 141): 'This principle needs no search and no invention, having long been in the reason of all men and embodied in their being. It is the principle of ethics' (CPR: 210). 
To Heidegger these statements sound quite peculiar. Is the law of finite pure willing undeniably and immediately evident to the commonest reason? Is it a fact embodied in the essence of man? Is it always present and can we confirm it at any time, as if with our nose and ears? Heidegger does not agree with Kant's understanding of the actuality of the law of finite pure willing as an object present-at-hand (vorhanden): 'It could also be conceded that this fact represents a specific kind of factuality quite different from that pertaining to present things...' (GA 31: 291). And this rejection of the self-evidence of the law of finite pure willing is phenomenologically motivated. If we observe ourselves in a completely unprejudiced way, we do not discover this law as a present-at-hand object within ourselves.

For Heidegger, therefore, the question remains what is the ontological status of the actuality of the law of finite pure willing. To answer this question, once again Heidegger takes up a notion of Kant. According to Kant we become conscious of the law 'as soon as we construct (entwerfen) maxims of the will' (CPR: 141; emphasis added). This condition of the possibility of experiencing the factuality of the law means that we move ourselves into the specific realm of such facts, i.e. that we actually will. The law of finite pure willing is solely in willing it.

According to Heidegger, this factuality of the law of finite pure willing is actual in a twofold sense. Firstly, the actuality of the law only gives itself through and in our willing it. Secondly, it is only this actuality of the law that is proper to our will as will. The law of finite pure willing is in fact only because and insofar as the will wills it, and the will is only in the ought demanded by pure willing, i.e. by the law of finite pure willing. Pure willing and the law of finite pure willing are therefore interconnected and interdependent.

We see here that Kant's concept of the will is criticized to remind us of three main characteristics of the will: 1) the self-orientation of willing consist in the fact that the cause of willing is found in our actual willing itself. 2) In actual willing, the one who wills and that which is willed are interdependent and interconnected. 3) This interdependency of the one who wills and that which is willed has the character of law-giving, i.e. of a 'you ought'.

When Heidegger uses the concept of the will in the beginning of the thirties, it is only in this manner, which was phenomenologically motivated; the law of willing is not a present-at-hand object within us, but accessible only via a knowledge that arises from such willing: 'the fact of the ought announces itself in the actual willing' (GA 31: 290; emphasis added). According to Heidegger this factuality of the ought can never be encountered as long as we consider and analyse the law of finite pure willing and ourselves as present-at-hand objects. 


\section{ii. Heidegger's Phenomenology of the Will in his Confrontation with}

Nietzsche (1936-37)

In the mid-thirties, we find a lecture course of 1936-37 on Nietzsche's will to power as art. In the second chapter of this lecture course, Heidegger develops his phenomenology of the will in confrontation with Nietzsche's concept of the will. In this section, we will discuss Heidegger's phenomenology of the will in his lecture course of 1936/37, in order to develop our understanding of Heidegger's concept of willing.

According to Nietzsche, will does not indicate a psychological phenomenon, but rather the Being of beings: 'Only where there is life, is there also will; not, however, Will to life, but - I teach you - Will to power' (KSA 4: 149). In his lecture course, Heidegger stresses the ontological status of Nietzsche's concept of the will: if, according to Nietzsche, will to power is the nature of all beings, then its definition cannot appeal to a particular being or to specific circumstances in the world. ${ }^{17}$ Heidegger illustrates this with an example.

Normally the will is taken to be a faculty of the soul. ${ }^{18}$ The soul is a particular being, for example distinct from body and mind. However, if the will provides the essence of every being, then it does not pertain to the soul. Rather, the soul, the body and the mind pertain to the will, inasmuch as such things are. Neither can the will be understood as an ability or power of the soul, in contrast to, for example, the ability to perceive. According to Heidegger, each ability is already a power to do something, and as such already a will to power. The will can therefore not be characterized by defining it as a faculty of the soul, because the essence of every faculty is already grounded in the essence of the will to power: 'If will to power characterizes Being itself, there is nothing else that will can be defined as. Will is will' (GA 43: 45).

Because the will cannot be identified with a being that is willing something, or with something that can be willed, the starting point of Heidegger's phenomenology of the will is found in the phenomenon of willing. Willing is a kind of behaviour directed towards something, a going after. Now it seems to be obvious that the essence of willing as directedness towards something would be grasped most purely by distinguishing it from other modes of directedness towards something, like representing or wishing for instance. However, this approach is inappropriate according to Heidegger: 'No, willing is not wishing at all. It is the submission of ourselves to our own command, and our exposure (Entschlossenheit) to such self-command, which already implies our carrying out the command' (GA 43: 47).

Heidegger recognizes that this account of willing seems to be unphenomenological at first sight, i.e. that it cannot be derived from the willing directedness towards something. But according to Heidegger, it is rather the isolation of willing (relation) of the one who wills and that which is willed (relata), and the comparison of this 'pure' relation with other relations - the 
representing or wishing relation for instance - which is unphenomenological. Willing does not exist without the one who wills and that which is willed; what is willed and the one who wills are brought into the willing relation according to Heidegger, 'although not in the extrinsic sense in which we can say that to every striving belongs something that strives and something that is striven for' (GA 43: 48). In this characterisation of the will in his lecture course of 1936/37, we recognize the same interconnectedness and interdependency of the one who wills and that which is willed in willing that we encountered already in the 1930 course. The question is, however, how in Heidegger's view the one who wills and that which is willed belong together in the willing relation. He explains this interconnectedness of willing by discussing Nietzsche's characterization of the will as affect and feeling.

When Nietzsche defines the will in relation to concepts such as affects and feelings, we are tempted to understand the psychological quality of these terms in a subjective way. Yet Heidegger keeps open the possibility that the will is not primarily the will of the subject: 'Will as mastery of oneself (Über-sich-Herrsein) is never the encapsulation of the ego from its surroundings' (GA 43; 56). Just as Heidegger tries to conceive the will starting from the willing relation and not on the basis of the relata (the one who wills or that which is willed), he also understands affects and feelings primarily as relational: 'We must above all see that here it is not a matter for psychology [...] It is [...] a matter of the ways man confronts the $D a$, the openness and concealment of beings, in which he stands' (GA 43; 52). An affect is primarily a mode of being (Seinsweise), in which the one who wills and that which is willed are interconnected. We follow Heidegger's lecture course for a moment in order to develop an answer to our question how the one who wills and that which is willed belong together in the willing relation.

An affect, anger for instance, comes over us, seizes us, and affects us. Our being is moved by a kind of excitement; something stirs us up and lifts us beyond ourselves. Heidegger conceives a first essential moment in the affect by appealing to popular speech:

Popular speech proves to be keen-sighted when it says of someone who is stirred up and acts in an excited manner, "He isn't altogether himself". When we are seized by excitement, our being "altogether there" vanishes; it is transformed into a kind of "falling apart" (auseinander) (GA 43: 53).

According to Heidegger, Nietzsche has this first essential moment in the affect in mind when he calls the will an affect. Willing is being lifted beyond oneself (über-sich-hinaus-wollen/sein), insofar as the one who wills and that which is willed "fall apart" in willing and as such initiate this über-sich-hinauswollen/sein ${ }^{19}$; the one who wills is lifted beyond oneself, namely towards that which is willed.

According to Heidegger, Nietzsche has also a second essential moment in the affect in mind when he calls the will an affect; the moment of seizure in the 
affect, by which something comes over us. When the will assaults or comes over us, this does not mean that we first exist and then will something. We are always in the scope of willing, even when we are unwilling. 'That genuine willing which surges forward in our exposure (Entschlossenheit) to it, that "yes", is what instigates the seizure of our entire being, of the very essence within us' (GA 43: 54-55). Heidegger conceives being-beyond-oneself (first essential moment in the affect) as the ex-posure (Entschlossenheit) of willing (second essential moment in the affect). ${ }^{20}$ Ent-schlossenheit means that the will has already said farewell to 'the encapsulation of the ego from its surroundings' (subjectivity) and exposes itself to 'the $D a$, the openness and concealment of beings, in which he stands' (Dasein). This does not mean, however, that the one who wills is abandoned in favour of that which is willed in willing. Willing ex-poses itself towards the one who wills as the one who is willed in willing (cf. GA 43: 48). With this, it becomes clear that the interconnectedness and interdependency between the one who wills and that which is willed has to be understood as a circular movement; the one who wills and that which is willed are interconnected in the mutual exposure (Entschlossenheit) of willing.

Heidegger argues that the interconnectedness of willing has the character of law-giving: 'Willing is the ex-posure to self-command' (GA 43: 47). This exposure to self-command concerns the exposure to the command of the one who wills (self) to be that which is willed in willing. At the same time, this self only is in its exposure to this command; willing wills the one who wills as that which is willed. ${ }^{21}$ In this characterization of the will as self-command, we recognize the law-giving character of willing we encountered already in the 1930 course. There we saw that finite pure willing has the character of lawgiving. Furthermore, we saw that this law of finite pure willing is actual in a twofold sense: the law of finite pure willing is only insofar as the will wills it, and the will is only insofar as it obeys the law of finite pure willing. Also in his lecture course of 1936-37, Heidegger argues that the law-giving character of willing - its exposure to self-command - is twofold.

Heidegger distinguishes between two aspects of the self-command of willing in his lecture course. The one who wills can only will to be that which is willed, when both are not identical. I can only will something when it is not already there. If the one who wills were identical to that which is willed, then there would be no necessity for him to be that which is willed in willing. Entschlossen is willing therefore only, if that which is willed is beyond the one who is willing it and, as such, awakens the willing directedness towards that which is willed; in willing, the one who wills determines that which is willed (Sichbefehlen). At the same time, the one who wills is not an isolated being who decides to will that which is willed. 'Only he can truly command ... who is always ready and able to place himself under command. By means of such readiness he has placed himself within the scope of the command as first to 
obey, the paragon of obedience' (GA 43: 49). It is not our decision to will that which is willed, according to Heidegger. The will itself has a moment of seizure that comes over us: 'That we can be beyond or outside ourselves in this or that way, and that we are in fact constantly so, is possible only because will itself seen in relation to the essence of man - is seizure pure and simple' (GA 43: 54). In the self-command of willing, that which is willed determines the one who wills (Sichbefehlen). It is in this double sense of self-commanding, that the lawgiving character of Heidegger's concept of the will has to be understood.

Finally, we also encounter the self-orientation of willing in Heidegger's concept of the self-command. To understand the self-orientation of willing, we return to our earlier characterization of willing as 'being lifted beyond ourselves'. We have already seen that willing is not just ecstatic or lifted beyond itself. Heidegger is quite specific here and understands 'being lifted beyond ourselves' as a way of 'losing ourselves'. So in one way or another, the concept of willing is connected with the question about ourselves; the 'falling apart' of the one who wills and that which is willed in willing, is the falling apart or cleavage between 'self' and (authentic or original) 'self'. It is precisely this cleavage or difference which can be seen as an impetus for the directedness of willing to bring the self to the (original) self: 'But such reaching out in passion does not simply lift us up and away beyond ourselves. It gathers our essential being to its proper ground' (GA 43: 56). Heidegger's primary concern here is self-assertion (Selbstbehauptung): 'Power is will as willing out beyond itself, precisely in that way to come to itself, to find and assert itself in the circumscribed simplicity of its essence, in Greek, entelecheia' (GA 43: 74, my emphasis). Heidegger's concept of willing is therefore self-oriented: 'Willing always brings the self to itself; it thereby finds itself out beyond itself. It maintains itself within the thrust away from one thing toward something else' (GA 43: 61, my emphasis). The self-orientation of willing concerns the interest to bridge the gap between self and (original) self, which is understood as the 'gathering of our essential being to its proper ground' or as 'a going back into its essence, into the origin' (GA 43: 70, my emphasis). With this, it becomes clear that willing is primarily concerned with the unity of self and original self and is therefore characterized by self-interest.

In conclusion, based on Heidegger's lecture courses of 1930 and 1936/37 we can discern three main characteristics of Heidegger's concept of the will: 1) the self-interest of willing, 2) the interconnectedness of willing and 3) the law-giving character of willing.

\section{Critical Assessment of Heidegger's Phenomenology of Willing:} the Subjectivity of the Self and the Self-interest of Willing.

Is Heidegger's concept of the will new when we compare it with other conceptions in the philosophical tradition? First of all, we recognize his general 
critique on the metaphysical tradition in his conception of the interconnectedness of willing. According to Heidegger, the metaphysical tradition does not ask thematically about Being. The point of departure are beings and what is asked for is the being of these beings. Also in case the concept of the will is reflected upon in the metaphysical tradition, the point of departure is found in beings; the one who wills or that which is willed. Unlike this tradition, Heidegger is asking for the will as such, i.e. willing. And because of this radically different orientation in his reflection on the will, he encounters the interconnectedness of the one who wills and that which is willed in willing.

Also the third characteristic of willing - its law-giving character - is quite new when we compare it with the metaphysical tradition. Of course, also Kant and Nietzsche pointed to the law-giving or commanding character of the will, but the interdependency of Sichbefehlen and Sichbefehlen in willing signifies that human being is not the subject who prescribes itself its own laws, nor the object of such a prescription. For Heidegger, we miss the law-giving character of willing as long as our point of departure is found in a being, i.e. in a subject who wills an object that is willed or vice versa.

What about the self-interest of willing as the first characteristic of Heidegger's concept of the will? In his lecture Nietzsche's Word 'God is dead' from 1943, based on the Nietzsche lectures delivered between 1936 and 1940, he writes the following about the essential character of the will:

To will is to will-to-be-master. ... Will strives for what it wills not just as for something that it does not yet have. What the will wills it has already. For will wills its willing. Will wills itself. It exceeds itself. In this way will as will wills above and beyond itself, and therefore at the same time it must bring itself beneath and behind itself. ${ }^{22}$

Heidegger here interprets the circular movement of the self-interest of willing as the essence of subjectivity, where the will always wills out beyond itself (ecstatic) and brings the other-than-itself back into the domain of this self (incorporation) ${ }^{23}$ : 'Since will is the overpowering of itself, no richness of life will satisfy it. It has its power in overreaching - namely, in reaching over its own will. Thus it, as the same, is constantly coming back unto itself as the same' (GA 5: 237). Heidegger now understands the concept of the will as anchored in a 'menschlicher Vorgriff', i.e. in the human being as a subject that is willing something 24 : 'With the subjectity of the subject, will comes to light as the essence of that subjectity' (GA 5: 243). Heidegger's later critique is, therefore, that the self-interest of willing is the essence of subjectivity.

Do we agree with Heidegger's subsequent critical remarks on the concept of the will? If he is right, we eventually have to conclude that his concept of willing bears witness to the reductive character of the will and that it therefore is not suited to find a path between Scylla - the reductive will - and Charybdis the releasement of willing. But we come to another conclusion. Based on our interpretation of the development of Heidegger's phenomenology of the will 
during the thirties $(\S 1)$, we are able to criticize his later rejection of the will in a more systematic way.

Instead of rejecting the will because of the subjective self-interest of willing, we ask the preliminary question whether the self-interest of willing is selfevident or not. Where does it come from, and is it phenomenologically motivated? For Heidegger, this is no question at all in his 1936-37 lecture course. When he characterizes the will, he self-evidently presupposes that the one who wills (self) is primarily willing himself as that which is willed (self), and not, for instance, the other of the one who wills, the other or the world. Despite his meticulous phenomenology of willing in the early and mid-thirties, a justification of this self-interest of willing is not provided.

According to Jacob Rogozinski, Heidegger's analysis depends on the modern philosophical tradition: 'The Heideggerian analysis depends upon, without ever calling into question, the dominant interpretation since Hegel of Kantian autonomy as "will which wills will", as the power of the Subject to prescribe itself its own laws'. ${ }^{25}$ In the modern philosophical tradition - from Kant to Nietzsche - the freedom, self-determination and selfhood of the willing subject is at the centre of philosophical attention. According to Fichte, to give only one example, the will is 'the authentic basic root of human being'. When we will something, we simultaneously will ourselves as a free being: 'I find myself, as myself, only in willing', i.e. only in willing do we have an experience of ourselves, according to Fichte. ${ }^{26}$ This example illustrates that the connection between will and self is self-evident in the modern philosophical tradition. And also Heidegger's presupposition of the self-interest of willing may be rooted in this tradition. ${ }^{27}$

But this presupposition is not only questionable. We even have to reject the self-interest as third characteristic of the will, because it undermines the other two characteristics of willing we discerned in the previous section; the interconnectedness of the one who wills and that which is willed and the lawgiving character of willing. To what extent is this the case?

The inter-connectedness of willing presupposes the remaining inter-inter as the in between, the principle and irreducible difference which pervades willing - between the one who wills and that which is willed, whereas the selfinterest of willing reduces this inter to the same (self). In the same way, the actuality of law-giving presupposes the remaining difference between the one who wills and that which is willed - the willing directedness is only factual when the one who wills and the willed are not identical - whereas the selfinterest of willing reduces this difference to identity (self). From a phenomenological point of view, we therefore have to reject the self-interest of willing in favour of the interconnected and law-giving character of actual willing: The one who wills (self) is not primarily willing himself, but the other of the one who is willing, the other or the world. 
Our critical reflection on Heidegger's phenomenology of willing shows, first of all, that it is not necessary to assume the self-interest of willing and secondly, that this self-interest undermines the other two characteristics of willing. We reject therefore the self-interest as a main characteristic of willing in favour of its interconnectedness and law-giving character. Furthermore, because it is precisely the self-interest of willing which can be seen as the root cause of the subjective character of willing, we do not have to reject the concept of the will completely as Heidegger did. On the contrary, our rejection of the self-interest of willing enables us to extend his phenomenology of willing in order to find a proper concept of the will which exceeds the reduction of otherness to sameness, difference to identity, by the subject. The two essential moments in the affect, as discussed in section one, can help us with this.

We saw that willing is the exposure to that which is beyond oneself, to the other of the one who wills, the other or the world (first essential moment in the affect). This 'being lifted beyond oneself' already shows that willing is not primarily self-interested, but is interested in the other of oneself, in the other or the world (world-interest). This world-interest of willing is confirmed by the second essential moment in the affect, the moment of seizure or assault. If something comes over us or assaults us in willing, then it is the other or the world itself. In willing, the other or the world assaults us in our ecstatic existence out into the world. Contrary to the self-interest of willing therefore, we introduce world-interest as the main characteristic of our proper concept of the will. To what extent does the world-interest of willing enable us to avoid the subjective tendency of willing?

Our rejection of the self-interest of willing does not mean we reject any connection of willing to the self. On the contrary, in willing, the one who wills exposes himself to the other of himself, to the other or the world, and the other or the world comes over him at the same instance. The self is not rejected in our concept of willing, but is involved in his exposition to the other or the world.

This exposing involvement of the self is indeed willing the other or the world, but can no longer be understood in a subjective way. When we reject the selfinterest of willing in favour of the interconnectedness of the one who wills (self) and that which is willed (the other or the world) in willing, we avoid the traditional dualism of man as subject and world as its object. What is primary is the willing relation, in which the one who wills exposes himself to that which is willed, while that which is willed comes over the one who is willing at the same time. The one who wills (self) and that which is willed (the other or the world) are mutually involved in the willing relation, and have to be understood as knots in the willing relation. This willing relation constitutes the one who wills and that which is willed, and not the other way around.

This is, however, merely the first step in our extension of Heidegger's phenomenology of willing. The critical reader may raise the question whether 
this concept of willing suffers from the same problem as encountered with the reduction of otherness to sameness, difference to identity. If the one who wills exposes himself to that which is willed and vice versa, our concept of willing suffers from a circularity that prevents us from distinguishing between the one who wills and that which is willed; in his exposition to the other or the world, the one who wills becomes 'nothing' and at the same time 'everything'. This circularity shows the pathos of unity which is characteristic of the interconnectedness of willing. So, although the interconnectedness of willing guarantees that willing is no longer subjective, the inter or difference threatens to become obscured by the same interconnectedness when the one who wills and that which is willed coincide in the willing relation.

If we recognize that the interconnectedness of willing presupposes the pathos of unity of willing on the one hand, and is being destroyed by the same pathos of unity on the other, we see the necessity to introduce a second pathos of willing in order to keep the remaining 'inter' between the one who wills (self) and that which is willed (the other or the world) open; a pathos of difference. The law-giving character of willing, discussed in section one, can help us to characterize this pathos of difference.

For Heidegger, willing is the self-command of the one who wills, namely the self-command to the one who wills to be what is willed. If we recognize that the actuality of law-giving presupposes the remaining difference between the one who wills and that which is willed, we see that willing can not only be characterized by the self-command to the one who wills to be that which is willed (pathos of unity), but also by the law to keep open the remaining inter or difference between the one who wills and that which is willed (pathos of difference). Why? On the one hand, the inter-connectedness of willing presupposes the remaining inter or difference between the one who wills and that which is willed, as we saw before. On the other hand, because this inter threatens to become obscured in the circularity of willing, only a law of willing is capable of commanding the self and the other of the self, the other or the world, not to be absorbed in this circularity and to keep open the difference between the one who wills and that which is willed in the interconnectedness of willing. Therefore only a law of willing is able to guarantee the interconnectedness of the one who wills and that which is willed in the willing relation. The law of willing has to be understood as this pathos of difference.

\section{Conclusions}

After our interpretation of Heidegger's phenomenology of willing in $\S 1$ and our critical assessment of the self-interest of willing as the root cause of the subjectivity of willing ( $\$ 2)$, we continued Heidegger's phenomenology of willing in order to find a proper concept of the will. Now we are prepared to come back to the main question of this article, namely, whether our concept of 
willing is suitable for finding a path between Scylla - the reductive will - and Charybdis - the releasement of the will.

In the first place, the exposing involvement of the self is indeed willing the other or the world. Therefore, our proper concept of the will is in no way to be understood as the releasement of willing. In fact, our concept of willing is characterized by an interest in the other or the world in the mutual involvement of the one who wills (self) and that which is willed (other or world). This worldinterest is the first characteristic of our proper concept of the will. The inter-connectedness is the second characteristic of our concept of the will, which prevents a subjective interpretation of it. The third characteristic has to be found in the law-giving character of willing, which prevents that the inter or difference between the one who wills and that which is willed becomes obscured in the circularity of willing (pathos of unity); the law-giving character of willing establishes and keeps open the remaining inter or difference between the one who wills and that which is willed in the interconnectedness of willing (pathos of difference).

And here, we experience a glimpse of the necessity to rehabilitate the will in contemporary philosophy. Willing is not only characterized by the ecstatic involvement in the interconnectedness of willing, but is also responsible for keeping open the inter or difference in willing the other or the world. The factuality of the remaining difference does not stand over against us, but has to be willed; the one who wills and that which is willed are responsible for keeping open this remaining difference in willing.

Of course this does not mean to say that the self is responsible for the other or the world itself. It is impossible to take a responsibility for that which is not mine. The responsibility of the one who wills and that which is willed, is to withstand the totality of the pathos of unity - the reduction of otherness to sameness, difference to identity - and to establish the pathos of difference in willing, to make and establish the difference between the one who wills and that which is willed, between self and world. Only by establishing this difference in willing will self and world not become obscured in the interconnectedness of willing, but be factual.

With our concept of willing, we have just taken the first step in such a rehabilitation. On the one hand, the question remains what is the impact of this concept of willing on our understanding of the intentionality of phenomenology (cf. Introduction). On the other hand, the question remains whether this concept of willing is compatible with Heidegger's thought of a 'human cor-respondence (Entsprechung) to the sending of Being' ${ }^{28}$

Wageningen University 


\section{References}

1. Friedrich Nietzsche, Kritische Studienausgabe, Band 4 (München/Berlin: de Gruyter, 1882/1887-1988), p. 146, hereafter cited as: KSA).

2. Emmanual Levinas, Totality and Infinity, trans. by Alphonso Lingis (Pittsburg: Duquesne UP 1987), pp. 216-253.

3. Martin Heidegger, Gelassenheit (Stuttgart: Neske, 1959), p. 30.

4. Karl Löwith, Martin Heidegger and European Nihilism, trans. by Gary Steiner (New York: Columbia University Press, 1995), p. 42.

5. Jürgen Habermas, The philosophical discourse of modernity, trans. by Frederick Lawrence (Cambridge/Massachusetts: MIT Press, 1990), p. 141.

6. Martin Heidegger, Sein und Zeit (Tubingen: Max Niemeyer Verlag, 1927-1993), p. 300. Quotations from Heidegger's writings will be given according to standard English translations of his work.

7. Martin Heidegger, Feldweg-Gespräche, Gesamtausgabe Band 77 (Frankfurt a.M: Vittorio Klostermann, 1995), pp. 108-109; cf. Martin Heidegger, Vorträge und Aufsätze, Gesamtausgabe Band 7 (Frankfurt a.M: Vittorio Klostermann, 2000), pp. 25-26.

8. Herman Philipse, Heidegger's Philosophy of Being. A Critical Interpretation (Princeton: Princeton UP, 1998), p. 309.

9. Cf. Richard Wolin, The Politics of Being: The Political Thought of Martin Heidegger (New York: Columbia UP, 1990), p. 150.

10. Brett Davis, Heidegger and the Will. On the Way to Gelassenheit (Evanston/Illinois: Northwestern University Press, 2007), p. 244; cf. pp. 216-248; cf. M.B. Tanzer, Heidegger: Decisionism and Quietism (New York: Prometheus Books, 2002).

11. With this question, we follow a different line of thought than Brett Davis proposes in his book. Also he argues that Heidegger's critics touch on certain genuine problematical issues, involved in the radicality of his thought path. 'These misapprehensions of Heidegger's turn toward a twisting free of the domain of the will indirectly suggest an insufficiency in articulation, or at least a tenuous subtlety, in his intimations of thinking non-willing(ly)'. He asks whether there is 'not a third possibility intimated in Heidegger's texts, namely that of a non-willing relation between man and being which exceeds the very domain of power and impotence?' (Brett Davis, Heidegger and the will, 244). In this article however, and contrary to Davis, we ask whether there is a willing relation between man and being which exceeds the very domain of power and impotence.

12. Martin Heidegger, Reden und andere Zeugnisse eines Lebensweges, Gesamtausgabe Band 16 (Vittorio Klostermann: Frankfurt a.M., 2000), p. 108; 117, hereafter cited as: GA 16. For Heidegger's destruction of the will in his Rectoral Address, see Vincent Blok, ,Heideggers "National Sozialismus" oder die Frage nach dem philosophischen Empirismus', Studia Phaenomenologica, 10 (2010), pp. 273-292.

13. Jacques Derrida, Of Spirit. Heidegger and the Question, trans. Geoffrey Bennington end Rachel Bowlby (University of Chicago Press: Chicago, 1989), p. 46. In his study of the twists and turns in Heidegger's thought with regard to the problem of the will, Davis for instance does not take into account the possibility that Heidegger's profound confrontation (Auseinandersetzung) with the concept of the will is phenomenologically motivated. For this discussion see Vincent Blok, "'Massive Voluntarism” or Heidegger's Confrontation with the Will”, Studia Phaenomenologica, Vol. 13 (2013), 449-465.

14. Parts of this section were published earlier in Studia Phaenomenologica, Vol. 13 (2013), 449465.

15. Immanuel Kant, Critique of Practical Reason, trans. Lewis White Beck (University of Chicago Press: Chicago, 1949), p. 128, hereafter cited as: CPR.

16. Martin Heidegger, Vom Wesen der menschlichen Freiheit, Gesamtausgabe Band 31 (Frankfurt a.M.: Vittorio Klostermann, 1994), pp. 276-279, hereafter cited as: GA 31.

17. Martin Heidegger, Nietzsche: Der Wille zur Macht als Kunst, Gesamtausgabe Band 43 (Frankfurt a.M: Vittorio Klostermann, 1985), p. 44, hereafter cited as: GA 43. 
18. This characteristic of the will is founded on Aristotle. He defines will (boulèsis) as a striving (orexis) which is connected to a rational representation and is located in the rational part of the soul (Aristotle, de Anima III, 9 (432b5-7)). For a comprehensive study on the will in Western philosophical tradition, see: Thomas Pink, M.W.F. Stone (ed.), The Will and Human Action: From Antiquity to the Present (London/New York: Routledge, 2004).

19. Cf. Martin Heidegger, Schelling: Vom Wesen der menschlichen Freiheit, Gesamtausgabe Band 42 (Frankfurt a.M: Vittorio Klostermann, 1988), p. 217.

20. With the concept of Entschlossenheit, Heidegger brings one of his own basic concepts of Being and Time in connection with Nietzsche's concept of the will. Normally, this word means resoluteness and indicates the resoluteness of the will of the subject. Literally nevertheless, Entschlossenheit means Ent-schlossenheit, 'unclosedness', i.e., not exactly will as the resoluteness of the subject, but exposure to the openness and concealment of beings, in which the one who wills and what is willed are interconnected. 'Das Wesen des Wollens wird hier in die Ent-schlossenheit zurückgenommen. Aber das Wesen der Ent-schlossenheit liegt in der Ent-borgenheit des menschlichen Daseins für die Lichtung des Seins und keineswegs in einer Kraftspeicherung des Agierens. cf. Sein und Zeit §44 und §60. Der Bezug zum Sein aber ist das Lassen' (Martin Heidegger, Einführung in die Metaphysik, Gesamtausgabe Band 40 (Frankfurt a.M.: Vittorio Klostermann, 1983), p. 23, hereafter cited as: GA 40).

21. In 1930 already, Heidegger saw this character of the will: 'Everyone who actually wills knows: to actually will is to will nothing else but the ought of one's existence' (GA 31: 289).

22. Martin Heidegger, Holzwege, Gesamtausgabe Band 5 (Frankfurt a.M: Vittorio Klostermann, 1977), p. 234, hereafter cited as : GA 5.

23. cf. Brett Davis, Heidegger and the Will, p. 9.

24. cf. Martin Heidegger, Beiträge zur Philosophie (vom Ereignis), Gesamtausgabe Band 65 (Frankfurt a.M: Vittorio Klostermann, 1989), pp. 179-186.

25. Jacob Rogozinski, „Hier ist kein warum. Heidegger and Kant's Practical Philosophy”, in Heidegger and Practical Philosophy, ed. by F. Raffoul, F., D. Pettigrew (New York: State University of New York Press, 2002), p. 50.

26. Quoted in J. Ritter et al., Historische Wörterbuch der Philosophie, Band 12 (Basel: Schwabe Verlag, 1971-2005), p. 784.

27. In this article, we focus on our main question and leave the question about the explanation of the self-interest of willing in Heidegger's philosophy aside. For this, see the excellent article of Rogozinski, who admits the difference between the modern philosophical interest in the human subject and Heidegger's interest in Dasein, but nevertheless points to the "existential solipsism" in his understanding of Dasein.

28. I would like to thank the reviewers of The Journal of the British Society for Phenomenology for their comments on earlier drafts of this article. 